\title{
Hyponyms of Insect in Ovoko Lect
}

\author{
EZE, Jacinta Ukamaka \\ Department of Linguistics, Igbo and Other Nigerian Languages, University of Nigeria, Nsukka, Nigeria \\ MAMAH, Juliana Ginika \\ Department of Linguistics, Igbo and Other Nigerian Languages, University of Nigeria, Nsukka, Nigeria \\ $\mathrm{ABOH}$, Sopuruchi Christian \\ Department of Linguistics, Igbo and Other Nigerian Languages, University of Nigeria, Nsukka, Nigeria \\ ARUAH, Virginus Onyebuchi \\ Department of Linguistics, Igbo and Other Nigerian Languages, University of Nigeria, Nsukka, Nigeria
}

\begin{abstract}
Earlier researches have focused on hyponymy in different languages. There appears to be lack of research in the study of hyponyms of insect in a dialect of Igbo. As such, this study examines the hyponyms of insect in Ovoko lect. The objectives of the study are to identity hyponyms of insects in Ovoko lect and classify them based on their superordinate terms or hypernyms. The study employs componential analysis in the analysis of data which were drawn from introspection and confirmed by selected native speakers of Ovoko lect. The study discovers that there are so many hyponyms of insect in the lect under study and all the hyponyms of insect therein are hyponyms in other levels. The study also shows that all the co-hyponyms in every superordinate term, though have their peculiar features, share some features in common which include them under such superordinate term. The researchers, therefore, recommend more study on the topic to help expand the vocabulary of the Igbo language.
\end{abstract}

Index Terms - hypernyms, componential analysis, co-hyponyms, Ovoko lect, semantics

\section{INTRODUCTION}

Semantics is generally known as the study of meaning. Determining the meaning of meaning has been a controversial issue in linguistic studies. In trying to explain why meaning failed to be conceptualized, Yule (1996) argues that in semantics, the focus is often on what words ordinarily mean as against what the speaker of the word has in mind in the context. There are two schools of thought in semantics which are traditional semanticists and linguistic semanticists. While the traditional semanticist contends that words have exact meaning and definite definitions, the linguistic semanticists believe that there is no definite meaning arguing that a set of words or meanings can be associated with a particular word or form (Anagbogu Mbah \& Eme, 2010). Linguistic semanticist studies semantics at two grammatical levels: word level and sentence level. At world level, semanticists are concerned with the meaning relationships that exist between words in a language. This is conceptualised as sense relations and which include synonymy, antonymy, hyponymy, homonymy, polysemy, etc. As Saussure rightly puts it, words are signs and their relationship to the world is symbolic that they signify concepts rather than things. This results from the fact that individual sign derives its meaning from its existence within a semantic field or related signs and not from the real world (Ani, 2017). In recent years, the study of terminology and specialised language have been undergoing cognitive shift which places a greater focus on conceptual representation and knowledge organisation (Benitez, 2009).

Hyponym, as one of sense relations, is a word whose semantic field is included within that of another word which is its hypernym. Two or more words that are related in a way that they can be classified under another umbrella term are called hyponyms (Anagbogu, Mbah \& Eme, 2010). Put differently, hyponym can be seen as a word, phrase or lexeme of narrower or more specific meaning that comes under a term with wider meaning. Examples of such are dog, cat, snake, bird, etc. under the term 'animal'. From this example, the word 'animal' is a superordinate term or hypernym; dog, cat, snake, bird are hyponyms of the word 'animal' and in essence relate to each other as 'co-hyponyms' in this context. In addition, a word can serve as a hyponym of more than one superordinate term. An example can be seen in the term 'eagle' which is a hyponym of 'bird' and as well as hyponym of 'animal' (Concise Oxford Companion to the English Language, 2018).

Hyponymy can be seen based on inclusion or on hierarchical relationship between terms. From the angle of inclusion, one can say that 'billy', 'nanny' and 'kid' are contained in superordinate term 'goat' because in their definitions 'goat' is involved. Example: a kid is a young goat while a nanny is an adult female goat. Taking it from the hierarchical perspective, one can see that a hypernym/superordinate term in a given level can become a hyponym in another higher level. Example can be seen in 'bird' which is a hypernym/superordinate term of hyponyms like eagle, wren, dove, pigeon, hawk, vulture, etc. and as well a co-hyponym with reptile, insect and mammal under the higher superordinate 
term 'animal' (Nordquist, 2018). The members of a category that best represent the category as a whole are its prototype.

On the other hand, insect is a small creature that has six legs. It is a member of the largest class of the phylum Athropoda which is itself the largest of the animal phyla (Wigglesworth, 2018). Insect has the following characteristics: chitinous exoskeleton, a three-part body (head thorax and abdomen), a three pairs of jointed legs, compound eyes and a pair of antennae. Insect is synonymous with ectognatha or entomida. Scientists posit that the most successful creature is insect and that out of about 1.5 million species of organisms on the planet, insects make up about two thirds of it (Hadhazy, 2015). This success is attributed to their tiny body size which helps hiding and reduces overall energy requirement wide diet of both natural and artificial foods, tough protective exoskeleton, frequent possession of wing which enhance their safety, grub and mates and again their prodigious ability to reproduce. Another fact about insects is their life span. Even through some live for only few days or weeks as reproducing adults, having spent longer period as larvae and pupae, there are still exceptions (Hadhazy, 2015). Out of numerous facts about insects is the fact that they are called by their unique names even though being so numerous. Every lect in a language has different terms for different insects. Ovoko as a lect in the Igbo language is not an exception.

The Ovoko lect is a variety of the Igbo language which is an East Benue Congo language of Niger Congo phylum spoken in South Eastern Nigeria. It is spoken by the indigenous people of Ovoko which is in Igbo-Eze South Local Government Area of Enugu State. Ovoko is bounded by Uhunowere on the North, by Orba on the South, by Iheaka on the East and by Obukpa on the West. Apart from Obukpa which is in Nsukka Local Government Area and Orba which is in Udenu Local Government Area, other communities at its boundries are in Igbo-Eze South Local Government Area of Enugu State.

One way of linking environmental concepts is through the study of hyponymy. It is observed that in sense relations hyponymy is a less familiar term to most people among its co-terms like synonymy, antonym, polysemy, etc. On this note, studies carried out on hyponyms of insects in Ovoko lect of Igbo is lacking. As a result, this study seeks to identify hyponyms of insects in Ovoko lect and classifies them under their subordinate terms. This study generally examines hyponyms of insect, but specifically focuses on the hyponyms of insect in Ovoko lect. So many insects that are found in the environment in the area under study have their peculiar names different from the names common to the group of such insects. Some of these peculiar names are dying as a result of the fact that many children in this new age lack knowledge of them. Therefore, this study will be a way of keeping record of such terms and bringing them to the knowledge of the young generation in the community. It will also bring to light the subordinate term to which every named insect belongs. The research work will also serve as a way of enriching Igbo vocabularies and as a reference material for further researches in the area.

This research paradigm is a qualitative research one which adopts descriptive approach in the analysis of its data. The method of data collection is introspection as two of the researchers are competent speakers of the lect. The obtained data were confirmed by selected native speakers of Ovoko lect. The geographical area of the study is Ovoko in IgboEze South Local Government Area of Enugu State and the content area is sense relation, which is one of the preoccupations of semantics. The data are analysed using the tenets of componential analysis.

\section{THEORETICAL BACKGROUND OF THE STUDY}

This study employs the componential analysis propounded by Katz and Fodor (1963) in studying hyponyms of insects in Ovoko lect. Componential analysis (CA) is a theory of semantics which claims that meaning of any lexical item can be decomposed into its basic components. In other words, for any lexical item, there are isolable properties that can be used to determine its true semantic content. Componential analysts claim that semantic components permit a succinct characterization of lexical and sentence relation (Ifegwazi, 2016). In CA,words are deconstructed into semantic components, which constitute the total sum of the meaning in a word (Katz \& Fodor, 1963). In all, Bussmann (1996) conceives componential theory as the analysis of words through semantically structured sets of features having the presence or absence of a feature in reference

In componential analysis, therefore, binary features $(+)$ are used to characterize the inherent features of the lexical items. (+) indicates the presence of such feature while (-) indicate its absence. Examples as provided by Nwaozuzu (2013, p. 13) include:

Man is expressed as

+ Human

+ Adult

+ Male

Boy is expressed as

+ Human

- Adult

+ Male

Woman
is expressed as
+ Human
+ Adult
- Male
Girl is expressed as
+ Human
- Adult
- Male

Componential analysis has been extolled for its merits. First, it is effective in describing meanings and meaning relationships like hyponymy, entailment, and the grammatical behaviour of word classes. Second, the basic important features of language distinction are revealed in the area of semantics, especially to the speakers of the language. Third, 
its effectiveness in the description of grammatical morphemes and words is highly pronounced. Lastly, the words belonging to relatively closed lexical sets such as animals are easily described by using componential analysis (cf. Ifeagwazi, 2016).

Inasmuch as componential analysis can account for some of the content words, it cannot account for functional or grammatical words such as prepositions, conjunctions and pronouns. It does not have any universal features that are applied in distinguishing lexemes. However, componential analysis is apt in accounting for the objectives of the study since the study centres on insects, which belong to noun category. Therefore, it forms the framework of the study. In using CA as the theoretical framework for this research, some components of superordinate terms under insect will be used to identify differences between co-hyponyms of such superordinate term using binary number $( \pm)$. By so doing, the identified insects in the lect under study will be seen under their hierarchical relationships which are found under one superordinate term "insect".

\section{RELATED STUDIES}

Nakamura, Kobayashi, Ogawa and Toyama (2012) adopted a pattern-based approach in studying hyponymy relation acquisition for the agricultural thesaurus. The paper aimed to increase the vocabulary of an existing thesaurus using hyponymy relations. The main objective was to acquire AGROVOC - qualified candidates from the hyponymy relation of legal texts. Using a pattern-based approach to hyponymy relation acquisition, the study showed that over 1,000 terms were extracted, some of which have not been registers in AGROVOC despite agricultural related terms. Though the two works study hyponym, the present study is on hyponyms of insect while Nakamura et al.'s study dealt with hyponymy relations acquisition for the agricultural thesaurus.

Onoja (2014) compared hyponyms of cooking terms in English and Igala. In the study, he established that English and Igala share some similarities in some hyponyms by having some relationships in different areas and having equivalent lexical items. He observed that their major difference is that the English language has more cooking terms than the Igala language and this factor may be because English has borrowed widely. Ayegba (2018) conducted a comparative hyponymous study of kinship terms in Igala and English. The objective of the study was to compare English and Igala kinship terms with the aim of subjecting the differences and similarities of kinships terms of the two languages into analysis. The data for the study were gathered through introspection and analysed using componential analysis as a theoretical framework. Finding of the study showed that there is a good number of differences between English and Igala kinship terms which include: (a) English kinship system is purely classificatory while the Igala kingship system is both classificatory and descriptive (b) in English worldview of kinship the distinctions are made between close and distance kin relationship, but in Igala worldview of kinship, the idea of distant kin relationship is insignificant because of the strong feeling of genealogy that exist in Igala culture. The present study and that of Ayegba (2018) are focused on hypenymous study, but while Ayegba (2018) studies kinship terms in Igala, the present study is on the hyponyms of insects in Ovoko lect.

Atadoga (2018) examined the semantic field of kinship terms in the Igala language. The objectives of the study were to explore what constitute kinship terms in the Igala language, itemize some kinship terms in Igala and determine superordinate terms and hyponyms of kinship terms in Igala. The data for the study were sourced through interview and textbooks. The investigation revealed among others that father, mother, grandparent, in-law, and brother/sister are general superordinate terms for kinship terms that have other co-hyponyms in Igala.

Nyambura, Gathigia and Nyarigoti (2018) studied hyponyms in Gikuyu church sermons in Nyeri County, Kenya. The objective of the study was to look at hyponymy in Gikuyu church sermons with a view to interpreting the nexus between a hypernym and its hyponyms. The study also looks at the influence of gender on hyponyms used in Gikuyu church sermons. The study adopted the semantic field theory (SFT) for the analysis of data which were drawn from tape recording of eight live sermons delivered in the Presbyterian Church of East Africa (PCEA) in Nyeri County, Kenya. The study found that there are superordinate terms and sets of co-hyponyms manifested in Gikuyu Church sermons. It also noted that sense relation is used more by women than men in Gikuyu Church sermons. It concludes that hyponymy is employed in Gikuyu Church sermons in order to create prelateship between hyponyms and superordinate terms. The relationship between this study and the present study is that both study hyponymy but while Nyambura et al. studied hyponyms in Gikuyu church sermons in Nyeri County, Kenya, while the present study is on hyponyms of insects in Ovoko lect.

From the related studies, it is observed a study of hyponyms in a variety of Igbo is lacking. The researchers could not come across any research work carried out on hyponymy in Ovoko lect. As a result of that, the researchers find it justified to fill the gap in literature by studying the hyponyms of insects in Ovoko lect.

\section{Data PRESENTATION AND ANALysis}

Insect in Ovoko lect is commonly known as "ụ́mụ ệhộh". As noted by Wigglesworth (2018), insect is the member of the largest class of the phylum arthropoda, which is itself the largest of the animal phyla. Semantically, insect is a superordinate term that houses a great number of other superordinate terms. "Ụ́mụ ệhộh" as they are commonly called in Ovoko are of different types, which include: 'ẹhóhá' (ants), 'ẹ́báshì' (crickets), 'ìgbélé’ (grasshoppers), énwū (bees), 
ẹ̀kókàrà (termites), íjījī (flies), chínchì (bedbugs), ùtú (weevils), ígwū (louse), ébélé (beetles), énwū (mosquitoes), ògwùgwù (butterflies), ùchíchā (cockroach), etc. All these are hyponyms of the term "insect" but are as well superordinate terms in another level.

In this study, some of the above mentioned insects are going to be analysed using componential analysis in a matrix table. Here, the data that will be used in the analysis are presented with their names in English language.

TABLE 1:

INSECTS AND THEIR HYPONYMS

\begin{tabular}{|c|c|c|}
\hline & Ovoko lect & English language \\
\hline & Ựmụ̀ ẹ́hḥ́họ́ & insects \\
\hline 1 & Ehọ́họ́ & ants \\
\hline $\mathrm{a}$ & Ákpórò & sugar ant \\
\hline $\mathrm{b}$ & Ńdā & regular ant \\
\hline $\mathrm{c}$ & Ńdá ōnwūnwū & ghost ant \\
\hline $\mathrm{d}$ & Òtá mpā & carpenter ant \\
\hline $\mathrm{e}$ & Ídò & fire ant \\
\hline $\mathrm{f}$ & Ákpọ́shị & pavement ant \\
\hline $\mathrm{g}$ & Áyáshì & jack jumper ant \\
\hline $\mathrm{h}$ & Íchékwúrú & Bullet ant \\
\hline $\mathrm{i}$ & Íjérè & Black army ant \\
\hline $\mathrm{j}$ & Ijéré mānụ̄ & Red army ant \\
\hline $\mathrm{k}$ & Ákpạshī ílòlò & Flying ant \\
\hline 1 & ẹ̀shí nè ẹshí áhª̀ & Flying ant \\
\hline 2 & İgbélé & Grasshopper \\
\hline $\mathrm{a}$ & İgwùrùbè & Locust \\
\hline $\mathrm{b}$ & Nshẹshẹ mánụ̄ & Long-horned grasshopper \\
\hline $\mathrm{c}$ & Óké òkə īgbēlē & Differential grasshopper \\
\hline $\mathrm{d}$ & İgbélé mā & Lubber grasshopper \\
\hline $\mathrm{e}$ & Òté pàkékə & Painted/rainbow/barber pole grasshopper \\
\hline$f$ & İgbélé égā & Pasture grasshopper \\
\hline $\mathrm{g}$ & Ǔrá & Forest grasshopper \\
\hline $\mathrm{h}$ & Èbəlèbà íshí ēkwē & Pygmy grasshopper \\
\hline $\mathrm{i}$ & Ónyé nwé àlə & Sprinkled grasshopper \\
\hline $\mathrm{j}$ & Òtə ḿkpəmè & Carolina grasshopper \\
\hline $\mathrm{k}$ & - Òñ́ạ mənyí ózo & Club-horned grasshopper \\
\hline 3 & È̀bạshị’ & Cricket \\
\hline $\mathrm{a}$ & Tétékwūrū & Mole cricket \\
\hline $\mathrm{b}$ & Nshẹ̀shẹ̀ ḿanụ̄ & Bush cricket/long-horned grasshopper/tree cricket \\
\hline $\mathrm{c}$ & Chị́chịgbẹ̄gbẹ̄ & Camel cricket/spider cricket/cave cricket \\
\hline $\bar{d}$ & Ė̉ọshị & Field cricket \\
\hline
\end{tabular}

From table 1 above, it can be seen that Ovoko lect is rich in vocabulary which they use to refer to different insects which are within their environment. At the surface level, one who is not conversant with these insects may classify all co-hyponyms of ant as ant as well as grasshopper and cricket. The importance of CA in this study is to deconstruct the salient features of the hyponyms of these insects.

The hyponyms of ẹ́họạ 'ant' in example 1 can be analysed using CA as in the matrix table below:

TABLE 2:

COMPONENTIAL MATRIX FOR ẹhạhạ́ 'ANT'

\begin{tabular}{|c|c|c|c|c|c|c|c|c|c|}
\hline & Insect & Flying & Biting & Stinging & Household & Ant & Black & Bigger & Wood \\
\hline Akporo & + & - & - & - & + & + & - & + & - \\
\hline $\mathrm{Nda}$ & + & - & - & - & + & + & + & - & - \\
\hline Nda onwunwu & + & - & - & - & + & + & - & - & - \\
\hline Ọta mpa & + & - & + & - & - & + & + & + & + \\
\hline Ido & + & - & + & - & - & + & - & \pm & - \\
\hline Akpəshị & + & - & - & + & + & + & + & - & - \\
\hline Ayashị & + & - & - & + & - & + & + & + & - \\
\hline Ichekwuru & + & - & + & - & - & + & + & + & - \\
\hline Ijere & + & - & + & - & - & + & + & - & - \\
\hline Ijere manx & + & - & + & - & - & + & - & - & - \\
\hline Akpəshị ilolo & + & + & - & + & - & + & + & + & - \\
\hline Eshị nẹ ẹshị $\mathrm{ah}^{\mathrm{w}} \mathrm{a}$ & + & + & - & + & - & + & + & - & - \\
\hline
\end{tabular}

The componential matrix above shows the feature(s), which a hyponym of 'ant' has or does not have. These features as can be seen in table 2 include: insect, flying, biting, stinging, household, ant, black, bigger and wood. From the table above, it is obvious that some ants are more related than others though they are all co-hyponyms in the hypernym 'ant'.

'Akporo' and 'uda' only contrasted at their size. 'Otampa' and 'ido' have their contrast at their colour and habitat only. 'Nda' and 'nda onwunwu' have their contrast at colour. 'Ẹshị nẹ ẹshị ahª'a' and 'akpəshị ilolo' contrast at their 
size. 'Ijere' and 'ijere manu' has theirs at colour. 'ichekwuru' and 'ijere' contrast at their size here. [+] sign shows that the feature is present in the insect while [-] sign shows absence of the feature in the insect.

Below is also the componential analysis of the hyponyms of the term grasshopper 'Igbele' in a matrix table.

TABLE 3:

COMPONENTIAL MATRIX FOR igbele 'GRASSHOPPER'

\begin{tabular}{|c|c|c|c|c|c|c|c|c|c|}
\hline & $\begin{array}{l}\text { Long } \\
\text { antenna }\end{array}$ & Insect & Flying & $\begin{array}{l}\text { Slant } \\
\text { face }\end{array}$ & Edible & Colourful & Stinks & Grasshopper & $\begin{array}{l}\text { Bigger } \\
\text { thorax }\end{array}$ \\
\hline Igwurube & - & + & + & - & + & \pm & - & + & + \\
\hline Nsheshe manụ & + & + & + & - & - & - & - & + & - \\
\hline Oke oke igbele & - & + & + & - & + & + & - & + & + \\
\hline Igbele ma & - & + & \pm & - & - & + & + & + & - \\
\hline Ote pakekə & - & + & + & - & - & + & - & + & + \\
\hline Igbele ẹgə & - & + & + & - & - & \pm & - & + & - \\
\hline Ụra & - & + & + & - & + & - & - & + & - \\
\hline Ebəle bə ishi ekwe & - & + & + & - & - & \pm & - & + & + \\
\hline Onye nwe alə & - & + & + & + & - & \pm & - & + & - \\
\hline Qtə mkpəme & - & + & - & - & - & - & - & + & - \\
\hline Qnə mənyi ozə & - & + & + & - & - & - & - & + & + \\
\hline Amịrọwa & - & + & + & - & - & - & - & + & - \\
\hline
\end{tabular}

The anatomy and functions of grasshopper are different from those of ant to an extent. As such, not all the same features that apply to ant apply to grasshopper. From the table above, some hyponyms of grasshopper are edible because of their nutritional contents whereas others are not.

The matrix above shows, just like that of ant, that some grasshoppers have more common components than others. Take for instance: 'Nsheshe manu' and 'an[rowa' have their contrast only at the length of their antenna. 'Onye nwe al' and ofe mkpme' have their contrast at the size of their thorax just as 'onə mənyi ozə' and 'amirowa'. Onye nwe alə' and Igbele egə have their own contrast at their shape of face. It is only three species of grasshoppers that Ovoko people eat.

\pm sign shows that such component may be present or absent in the grasshopper in the sense that such type of grasshopper has species in it where one exhibits such feature, the other does not.

The hyponyms of cricket 'ẹbəshị' can also be analysed using CA as in the matrix table below:

TABLE 4:

COMPONENTIAL MATRIX FOR ébọshị 'CRICKET'

\begin{tabular}{|l|l|l|l|l|l|l|l|}
\hline & Insect & Edible & Flying & Chirping & Household & Cylindrical & Cricket \\
\hline Ebəshị & + & + & + & + & - & - & + \\
\hline Tetekwuru & + & + & - & - & - & + & + \\
\hline Nshẹnçhẹmanụ & + & - & + & - & - & - & + \\
\hline Chịchịgbegbe & + & - & - & + & + & - & + \\
\hline
\end{tabular}

From the matrix above, it is clear that species of cricket have clear distinctive features. They do not share much features in common. However, they are all co-hyponyms in the hypernym "cricket". However, Ebashi is the prototype of the term ebashi in the lect. With this matrix and the features therein, one can easily identify any of the hyponyms of cricket where one sees them. This often applies to non-native speakers of Ovoko lect who have different names for these hyponyms.

\section{CONCLUSION}

From the study carried out above, it is discovered that there are so many hyponyms of insects in Ovoko lect such as 'ẹbəshi', 'igbele', 'ẹhəhə’, 'ụchicha', 'igwu', ‘ẹkəkara', 'ẹnwụ', 'ebele', 'ijiji', 'ogwugwu', etc. However, all the hyponyms of insects are hypernyms in other levels as different insects have different species that bear their unique names in the lect under study.

The analysis done above on 'ant', 'grasshopper' and 'cricket' shows that all the co-hyponyms in every superordinate terms share some features in common, which made them to be included under such superordinate term. However, they have their contrastive features which isolate them whenever their names are mentioned. For instance, the chirping household cricket in Ovoko lect is called chichigbegbe. This study has identified hyponyms of insects in Ovoko lect and classified them based on their superordinate terms in a way that will be beneficial to the enrichment of the Igbo language vocabulary.

The researcher encourages researchers to study topics in hyponymy in the Igbo language or its lects as that will enrich Igbo vocabulary. This is pertinent because in most cases, the Standard Igbo language may not have a word for the hyponyms of insects studied in this paper. As such, Igbo linguists may draw some terms from Igbo dialects and incorporate them in the Standard Igbo. 


\section{REFERENCES}

[1] Anagbogu, P. N., Mbah, B. M. \& Eme, C. A. (2010). Introduction to linguistics (2nd edn.). Awka: Amaka Dreams Ltd.

[2] Ani, E. N. (2017). Correlation between collocations and antonyms in Igbo. Seminar paper, University of Nigeria Nsukka.

[3] Atadoga, F. T. (2017). A study of the semantic field of kinship terms in Igala. PhD seminar paper, University of Nigeria, Nsukka.

[4] Ayegba, M. (2018). A comparative hyponymous study of kinship terms in Igala and English. PhD seminar paper, University of Nigeria, Nsukka.

[5] Benitez, P. F. (2009). The cognitive shift in terminology and specialized translation. https://www.researchgate.net (accessed on 29/11/18).

[6] Bussmann, H. (1996). Routledge dictionary of language and linguistics. London: Routledge.

[7] Concise Oxford Companion to the English Language (2018). Hyponym. https://www.encyclopedia.com> (accessed on 26/11/18).

[8] Hadhazy, A. (2015). 20 startling facts about insects. https://www.livescience.com (accessed on 29/11/18).

[9] Ifeagwazi, P. A. (2016). Componential analysis. In B. M. Mbah (ed.), Theories of linguistics. Nsukka: University of Nigeria Press Ltd, 154-166.

[10] Katz, J. J. \& Fodor, J. A. (1963). The structure of a semantic theory. Cognition 5, 189-214.

[11] Nakamura, M., Kobayashi, E., Ogawa Y. \& Toyama, K. (2012). A pattern based approach to hyponymy relation acquisition for the agricultural thesaurus. A paper presented in International Symposium on Agriculture Ontology Service (AOS 2012).

[12] Nordquist, R. (2018). What are hyponyms in English? https://www.thought.com/hyponym (accessed on 26/11/18).

[13] Nwaozuzu, G. I. (2013). The babelist theory of meaning. Nsukka: University of Nigeria Press Ltd.

[14] Nyambura, G. N. Gathigia, M. G. \& Ngarigoti N. (2018). Hyponyms in Gikuyu church sermons in Nyeri County Kenya. European Journal of Literature, Language and Linguistics Studies 2.2, 44-58.

[15] Onoja, P. (2014). Comparative analysis of hyponymy in English and Igala. M.A. thesis, Kogi State University, Anyigba.

[16] Wigglesworth, V. B. (2018). Insect. https://www.britannica.com/animal/ (accessed on 20/11/18).

[17] Yule, G. (1996). Pragmatics: In H. G. Widdowson (ed.), Introductions to language study. Cambridge: Oxford University Press, 105-160.

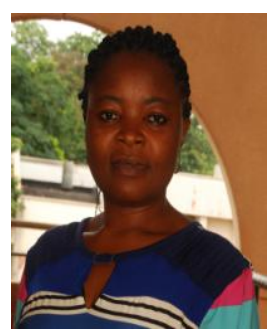

Jacinta U. Eze was born in Ovoko, Enugu State on 30th July. She has Bachelor of Arts Degree and Master of Arts Degree in Linguistics at the University of Nigeria, Nsukka. Jacinta specialises in Sociolinguistics and Discourse Analysis.

She has co-published "Slang usage amongst students in urban areas: An insight of Warri metropolis. Igboscholars International Journal of Igbo Scholars Forum, Nigeria, 13(1), 37-56.

Mrs. Eze is a member of Linguistic Association of Nigeria.

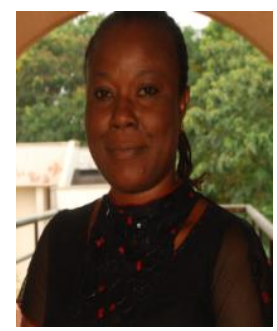

Juliana G. Mamah was born in Enugu Ezike, Enugu State on 10th August. She has Bachelor of Arts Degree and Master of Arts Degree in Linguistics at the University of Nigeria, Nsukka. Juliana specialises in Psycholinguistics.

She has co-published "Slang usage amongst students in urban areas: An insight of Warri metropolis. Igboscholars International Journal of Igbo Scholars Forum, Nigeria, 13(1), 37-56.

Mrs. Mamah is a member of Linguistic Association of Nigeria.

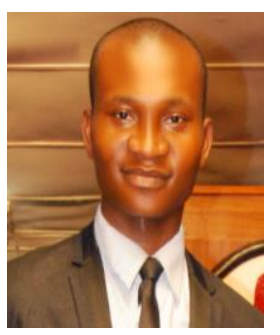

Sopuruchi C. Aboh was born in Aba, Abia State on 20th November. He had his Bachelor of Arts Degree and Master of Arts Degree in Linguistics at the University of Nigeria, Nsukka. Sopuruchi specialises in Sociolinguistics and Pragmatics.

He has published some articles including: "The ideology of post-truth in Nigerian cities: A discourse historical analysis", Journal of Linguistic Association of Nigeria, 22(1), 64-78 and "A comparative analysis of lexical prepositions in the Ibibio and Igbo languages", Macrolinguistics, 6(9), 36-45.

Mr. Aboh is a member of Pragmatics Association of Nigeria, Nigeria Ecolinguistics Association, and Nigerian Institute of Translators and Interpreters. 
Virginus O. Aruah was born in Nsukka, Enugu State on 24th January. He had his Bachelor of Arts Degree and Master of Arts Degree in Linguistics at the University of Nigeria, Nsukka. Virginus specialises in Applied Linguistics and Medical Discourse.

He has published "Igbo language teaching: An identity in school of General Studies, in Nigerian universities", Journal of African Studies and Sustainable Development, 2(5), 73-86, among others.

Mr. Aruah is a member of Igbo Studies Association and Linguistic Association of Nigeria. 